\title{
Laser and Its Hazard Potential
}

\section{Bettina Hohberger}

Department of Ophthalmology, University of Erlangen, Friedrich-Alexander-Universität Erlangen-Nürnberg (FAU), Erlangen, Germany

"Corresponding author: Bettina Hohberger, Department of Ophthalmology, University of Erlangen, Friedrich-Alexander-Universität Erlangen-Nürnberg (FAU), Schwabachanlage 6, 91054 Erlangen, Germany, Tel: +49-9131-8544497; E-mail: bettina.hohberger@uk-erlangen.de

Received date: June 25, 2016; Accepted date: August 19, 2016; Published date: August 27, 2016

Copyright: (C) 2016 Hohberger B. This is an open-access article distributed under the terms of the Creative Commons Attribution License, which permits unrestricted use, distribution, and reproduction in any medium, provided the original author and source are credited.

\begin{abstract}
Laser-induced eye injuries have been reported more and more often in the past years, yet the laser is not a modern invention. Based on stimulated emission, the wavelength, energy dose and pulse duration of the laser are the determining factors for its possible hazard potential. The eye, which is the most vulnerable body part for laser radiation, can be affected. As medical treatment is discussed controversial, a great demand has been put on developing laser protection gear. The present review summarizes the physical basics, clinical findings and therapeutic options of laser-induced eye injuries.
\end{abstract}

Keywords: Laser; Radiation; Eye injuries; Therapy

\section{Introduction}

Laser- (Light Amplification by Stimulated Emission of Radiation) induced eye injuries have increased in the last years. Accidental, as well as targeted injuries have been reported not only in private, and occupational settings, but also in the military. The basic concept of absorption and emission of light was reported for the first time in 1917, when Einstein talked about "the quantum theory of radiation" [1]. This was the fundament for the development of modern laser technologies. Several years later the first MASER (Microwave Amplification by the Stimulated Emission of Radiation) was developed by Townes et al. [2]. Collaboration between Dr. Townes and Dr. Schawlow provided first recommendations for the extension of MASER in the range of visible light [3]. It was finally in 1960 that Maiman et al. [4] published the first laser, using ruby. Since then, several investigations have been done to expand its application in research, clinical therapy, and industry and for human entertainment. It is anticipated that the use of laser will be extended in the next years, thus the exact mechanisms of the laser effect on diverse structures (e.g., ocular tissue) are of great interest. Concurrent to the increased interest in laser applications, is also a rise in developing protection against potential laser-induced injuries.

\section{Laser-physical characteristics}

Laser technology is based on the principle of simulated emission: an atom is excited by an external energy source to a higher energy level. If a photon with the same energy level as the difference of the excited electron and the lower energy level, contacts this excited electron, the latter one will drop on the lower energy level and emit a further photon. This emitted laser light is monochromatic, coherent and collimated [5]. The dimension of the laser-induced damage is dependent on three different factors: the wavelength, energy dose and pulse duration of laser radiation.

Radiation with short wavelength (ultraviolet) is absorbed in the cornea and could thus potentially damage the surrounding tissue via photochemical processes [6]. Visible light (380 $\mathrm{nm}$ to $1400 \mathrm{~nm}$ ) passes the ocular structures until the retina, whereas only radiation above a special level can cause severe injuries [7]. Radiation of longer wavelength (far-infrared) in comparison is absorbed by water with consecutive thermal damage of the cornea, even until corneal perforation $[8,9]$.

Pulse duration and energy level are interconnected when inducing eye injuries. Radiation with continuous-wave pulse duration emits constant radiation over a defined time period. Modulation of the pulse duration is possible, as "Q-switched" mode (i.e. short pulse duration with high energy levels) and mode-locked mode, which represents a series of short pulses [10]. Both of them can cause severe eye injuries due to their high energy level even at a long distance [11]. It is well known that radiation with high energy levels can induce severe injuries, however, radiation with low energy levels can also generate the same damage pattern when released in short pulses [12].

The pattern of injury is dependent on pulse duration and energy level. Radiation with low energy and long pulse duration (>several seconds) induce photochemical reactions [13], whereas shorter pulse durations (<seconds) will generate thermal damages in the surrounding tissues. If the pulse duration is even shorter (<nanoseconds), mechanical injuries can be caused due to a rapid release of heat [14].

\section{Laser-induced eye injuries}

Laser-induced eye injuries occur, regardless of the availability of safety glasses. Often they are caused accidentally, such as during a laser show [15] or by a cosmetic laser [16]. Accidental injuries by laser pointers with consecutive retinal affection were reported even after an exposure time of about 10 seconds [17]. Some reports of laser injuries were self-inflicted $[18,19]$. Unfortunately, the majority of the cases published in the past months have been tightly focused by strangers $[20,21]$.

The use of laser in industry and research has caused several industrial accidents [22,23]. Additionally, laser-induced injuries were reported in military misadventures [24-26]. In most of the cases the eyes were hurt during exercises or caused by inappropriate handling. Data from the US Army Safety Center, the US Army Center for Health 
Page 2 of 3

Promotion and Preventive Medicine, and the Walter Reed Army Institute of Research showed that most of the victims were affected by a Q-switched, Neodymium:YAG (Nd:YAG) laser (1064 nm) [27]. Due to the high repetition of short pulse duration (time periods of nanoseconds) of military lasers, the retinal is often affected multifocally [28].

\section{Laser-induced eye injuries - morphologic findings and therapy}

Laser radiation is graded into different groups according to its risk exposure. Laser until class 2 are known to be "safe", due to the sufficient protection by the normal lid closure. In higher classes, the normal ocular protection mechanisms fail and serve eye injuries can be induced (accident prevention regulation BGV B2, [Laserstrahlung], 01.04.1988, version 01.01.1997 with instructions from April 2007 status: January 2010 (print: 2011-01)). The victims of laser injuries typically report decreased visual acuity and visual field defects [19]. Corneal structures can be disrupted, reaching form photokeratitis until perforation $[8,29,30]$. The extent of intraocular damage however, is dependent on pupil size [31]. Vitreous [32], subretinal [33] or chorioretinal hemorrhages [32], as well as retinal edema or scars can also occur [34], and hypopigmentation [35], pigment clumps [36] and choroidal neovascularization [37] can develop. Even one month after an injury, macular holes may arise [38]. Macular pucker or epiretinal membranes were observed in some patients [39,40]. Beside the testing of visual acuity, measurements of the visual field (e.g., with perimetry, Bagolini test $[41,42]$ ) should be performed by clinicians. Additional information can be received by measuring of the Spectralis Domain OCT, as it offers the possibility to visualize the exact retinal damage $[19,20]$. Spectralis Domain OCT measurements are also recommended in clinical follow-up examinations.

The therapeutic procedure for laser damage has been discussed controversially. Administration of local and systemic antiinflammatory drugs (e.g., glucocorticoids, indomethacin) [43,44], as well as Nd:YAG hyaloidotomy or victrectomy [45] have been the medical or surgical options, yet recovery of visual acuity has not been consistent. Reports of an increase [46] as well as a missing of visual acuity after vitrectomy [47] can be found in literature. Even laserinduced macular holes do not require an immediate operation as they can close spontaneously [48]. However, there is no evidence-based recommendation for the treatment of laser-induced eye injuries. Several approaches were done using growth factors [49,50] or neuroprotective substances (e.g., MK-801 in animal model [51]; PN-277 in animal model [52]), however some of them are toxic for humans. Research on new medical treatment is ongoing with a focus on the aforementioned target structures.

\section{Conclusion}

Although there is a guideline of the International Commission on Non-Ionizing Radiation Protection (ICNIRP) for the exposure of laser [5], several accidents were reported accidentally or even tightly focused. It is recommended that laser radiation is totally encased. If this is not possible, a restriction of entrance, laser protection glasses and specific training courses should be offered. It is also recommended that the civil international trading of laser equipment via the internet be restricted for laser ( $\geq$ class 3 ) to prevent any inappropriate use.

\section{References}

1. Einstein A (1917) For quantum theory of radiation. Phys 18: 121-128.

2. Gordon JP, Zeiger HJ, Townes CH (1955) The MASER: New type of amplifier, frequency standard and spectrometer. Physiol Rev 99: 1264-1274.

3. Schawlow AL, Townes CH (1958) Infrared and optical masers. Phys Rev 112: 1940-1949.

4. Maiman TH (1960) Stimulated optical radiation in ruby. Nature 187: 493-494.

5. International Commission on Non-Ionizing Radiation Protection (2013) ICNIRP guidelines on limits of exposure to laser radiation of wavelengths between $180 \mathrm{~nm}$ and 1,000 $\mu \mathrm{m}$. Health Phys 105: 271-295.

6. Krauss JM, Puliafito CA, Steinert RF (1986) Laser interactions with the cornea. Surv Ophthalmol 31: 37-53.

7. Geeraets WJ, Berry ER (1968) Ocular spectral characteristics as related to hazards from lasers and other light sources. Am J Ophthalmol 66: 15-20.

8. Fine BS, Fine S, Peacock GR, Geeraets WJ, Klein E (1967) Preliminary observations on ocular effects of high-power, continuous co-2 laser irradiation. Am J Ophthalmol 64: 209-222.

9. Peppers NA, Vassiliadis A, Dedrick KG, Chang H, Peabody RR, et al. (1969) Corneal Damage Thresholds for CO(2) Laser Radiation. Appl Opt 8: 377-381.

10. Smart D, Manson N, Marshall J, Mellerio J (1970) New ocular hazard of mode locking in CW lasers. Nature 227: 1149-1150.

11. Barkana Y, Belkin M (2000) Laser eye injuries. Surv Ophthalmol 44: 459-478.

12. Kohtiao A, Resnick I, Newton J, Schwell H (1966) Threshold lesions in rabbit retinas exposed to pulsed ruby laser radiation. Am J Ophthalmol 62: 664-669.

13. Hillenkamp F (1980) Interaction between laser radiation and biological systems. Hillenkamp F, Pratesi R, Sacchi CA, editors. Lasers in Biology and Medicine, New York, Springer, USA. pp 37-68.

14. Marshall J (1970) Thermal and mechanical mechanisms in laser damage to the retina. Invest Ophthalmol 9: 97-115.

15. Sachs HG, Baumgathuber N, Lohmann CP (1998) Eye injuries during a laser show. Klin Monbl Augenheilkd 212: 163-165.

16. Shum JW, Iu LP, Cheung DN, Wong IY (2016) A case of accidental ocular injury from cosmetic laser burn. Retin Cases Brief Rep 10: 115-120.

17. Yolton RL, Citek K, Schmeisser E, Reichow AW, Griffith T (1999) Laser pointers: toys, nuisances, or significant eye hazards? J Am Optom Assoc 70: 285-289.

18. Weng CY, Baumal CR, Albini TA, Berrocal AM (2015) Self-induced laser maculopathy in an adolescent boy utilizing a mirror. Ophthalmic Surg Lasers Imaging Retina 46: 485-488.

19. Hohberger B, Bergua A (2016) Self-inflicted laser-induced maculopathy in adolescence. Ophthalmologe 1-9.

20. Hohberger B, Bergua A (2016) Laser-induced Maculopathy Caused by Strangers. Klin Monbl Augenheilkd.

21. Gosling DB, O'Hagan JB, Quhill FM (2016) Blue Laser Induced Retinal Injury in a Commercial Pilot at $1300 \mathrm{ft}$. Aerosp Med Hum Perform 87: 69-70.

22. Boldrey EE, Little HL, Flocks M, Vassiliadis A (1981) Retinal injury due to industrial laser burns. Ophthalmology 88: 101-107.

23. Barbanel CS, Ducatman AM, Garston MJ, Fuller T (1993) Laser hazards in research laboratories. J Occup Med 35: 369-374.

24. Gorsuch GM (1996) Laser injury. Navy Med 87: 23-26.

25. Lang GK, Lang G, Naumann GO (1985) Accidental bilateral asymmetric ruby laser maculopathy. Klin Monbl Augenheilkd 186: 366-370.

26. Mader TH, Aragones JV, Chandler AC, Hazlehurst JA, Heier J, et al. (1993) Ocular and ocular adnexal injuries treated by United States military ophthalmologists during Operations Desert Shield and Desert Storm. Ophthalmology 100: 1462-1467. 
27. Harris MD, Lincoln AE, Amoroso PJ, Stuck B, Sliney D (2003) Laser eye injuries in military occupations. Aviat Space Environ Med 74: 947-952.

28. Kearney JJ, Cohen HB, Stuck BE, Rudd GP, Beresky DE, et al. (1987) Laser injury to multiple retinal foci. Lasers Surg Med 7: 499-502.

29. Schulmeister K, Sliney DH, Mellerio J, Stuck BE (2008) Review of exposure limits and experimental data for corneal and lenticular damage from short-pulsed UV and IR laser radiation. J Laser Appl 20: 98-105.

30. Fine S, Feigen L, MacKeen D (1968) Corneal injury threshold to carbon dioxide laser irradiation. Am J Ophthalmol 66: 1-15.

31. Milsom PK, Till SJ, Rowlands G (2006) The effect of ocular aberrations on retinal laser damage thresholds in the human eye. Health Phys 91: 20-28.

32. Mainster MA, Stuck BE, Brown J Jr (2004) Assessment of alleged retinal laser injuries. Arch Ophthalmol 122: 1210-1217.

33. Boosten K, Ginderdeuren VR, Spileers W, Stalmans I, Wirix M, et al (2011) Laser-induced retinal injury following a recreational laser show: two case reports and a clinicopathological study. Bull Soc Belge Ophthalmol 317: 11-16.

34. Wyrsch S, Baenninger PB, Schmid MK (2010) Retinal injuries from a handheld laser pointer. N Engl J Med 363: 1089-1091.

35. Ueda T, Kurihara I, Koide R (2011) A case of retinal light damage by green laser pointer (Class 3b). Jpn J Ophthalmol 55: 428-430.

36. Sethi CS, Grey RH, Hart CD (1999) Laser pointers revisited: a survey of 14 patients attending casualty at the Bristol Eye Hospital. Br J Ophthalmol 83: 1164-1167.

37. Sun Z, Wen F, Li X, Wu D (2006) Early subfoveal choroidal neovascularization secondary to an accidental stage laser injury. Graefes Arch Clin Exp Ophthalmol 244: 888-890.

38. Bernstein PS, Steffensmeier A (2005) Optical coherence tomography before and after repair of a macular hole induced by an unintentional argon laser burn. Arch Ophthalmol 123: 404-405.

39. Alhalel A, Glovinsky Y, Treister G, Bartov E, Blumenthal M, et al. (1993) Long-term follow up of accidental parafoveal laser burns. Retina 13: 152-154.

40. Alsulaiman SM, Alrushood AA, Almasaud J, Alzaaidi S, Alzahrani Y, et al. (2014) High-power handheld blue laser-induced maculopathy: the results of the King Khaled Eye Specialist Hospital Collaborative Retina Study Group. Ophthalmology 121: 566-572.

41. Gajda B, Kiszka A, Koman E, Cisek A, Nowomiejska K, et al. (2016) Monitoring the visual field of a patient with secondary pseudotumour cerebri syndrome due to one-sided lymphadenectomy and internal jugular vein ligature - case report. Ophthalmology J 1: 67-71.

42. Kara K, Jünemann A, Redjak R, Hohberger B (2016) Glaucoma: Confrontation visual field test using Bagolini striated glasses-a new screening method for detecting visual field defects. Ophthalmol $\mathrm{J} 1$ : 18-23.

43. Hirsch DR, Booth DG, Schocket S, Sliney DH (1992) Recovery from pulsed-dye laser retinal injury. Arch Ophthalmol 110: 1688-1689.

44. Brown J Jr, Hacker H, Schuschereba ST, Zwick H, lund DJ, et al. (2007) Steroidal and nonsteroidal antiinflammatory medications can improve photoreceptor survival after laser retinal photocoagulation. Ophthalmology 114: 1876-83.

45. Ulbig MW, Mangouritsas G, Rothbacher HH, Hamilton AM, McHugh JD, et al. (1998) Long-term results after drainage of premacular subhyaloid hemorrhage into the vitreous with a pulsed Nd:YAG laser. Arch Ophthalmol 116: 1465-1469.

46. Isernhagen RD, Smiddy WE, Michels RG, Glaser BM, Serge DB, et al. (1988) Vitrectomy for nondiabetic vitreous hemorrhage: not associated with vascular disease. Retina 8: 81-87.

47. Custis PH, Gagliano DA, Zwick H, Schuschereba ST, Regillo CD (1996) Macular hole surgery following accidental laser injury with a military rangefinder. Proceedings of Laser-Inflicted Eye Injuries: Epidemiology, Prevention, and Treatment, Jan 29-30, 1996, San Jose, California. SPIE 2674: 166-175.

48. Thach AB, Lopez PF, Snady-McCoy LC, Golub BM, Frambach DA, et al. (1995) Accidental Nd: YAG laser injuries to the macula. Am J Ophthalmol 119: 767-773.

49. Schuschereba ST, Bowman PD, Ferrando RE, Lund DJ, Quong JA, et al (1994) Accelerated healing of laser-injured rabbit retina by basic fibroblast growth factor. Invest Ophthalmol Vis Sci 35: 945-954.

50. Wang X, Zhou X, Ma J, Tian H, Jiao Y, et al. (2010) Effects of keratinocyte growth factor-2 on corneal epithelial wound healing in a rabbit model of carbon dioxide laser injury. Biol Pharm Bull 33: 971-976.

51. Solberg Y, Rosner M, Turetz J, Belkin M (1997) MK-801 has neuroprotective and antiproliferative effects in retinal laser injury. Invest Ophthalmol Vis Sci 38: 1380-1389.

52. Shulman S, Belokopytov M, Dubinsky G, Belkin M, Rosner M, et al. (2009) Ameliorative effect of PN-277 on laser-induced retinal damage. Graefes Arch Clin Exp Ophthalmol 247: 343-348. 